Culture \& Society: Journal of Anthropological Research

VOL. 1 NO. 2 DESEMBER 2019

http://culture.ppj.unp.ac.id

Email: culture@ppj.unp.ac.id

ISSN: 2686-343X (E-ISSN) 2686-3421 (P-ISSN)

DOI: https://doi.org/10.24036/culture/vol1-iss2/17

\title{
Manjapuik Limau Sebelum Upacara Perkawinan \\ (Studi Etnosain Pada Masyarakat Jorong Rumah Panjang Nagari Selayo Tanang Bukit Sileh Kecamatan Lembang Jaya Kabupaten Solok)
}

\author{
Lola Resita ${ }^{1}$,Erda Fitriani', Desy Mardhiah ${ }^{3}$ \\ ${ }^{1,2,3}$ Universitas Negeri Padang \\ Email:1olaresita145@gmail.com.,_erdafitriani@fis.unp.ac.id, desy_padang@yahoo.com
}

\begin{abstract}
Abstrak
Artikel ini bertujuan untuk menjelaskan mengenai pengetahuan masyarakat Jorong Rumah Panjang dalam manjapuik limau sebelum upacara perkawinan dan mendeskripsikan keyakinan masyarakat Jorong Rumah Panjang penganut Islam terhadap kesaktian roh nenek moyang. Penelitian ini dianalisis dengan teori Ethnoscience yang dikembangkan oleh James P Spradley. Ethnoscience menekankan bahwa data yang disodorkan adalah data kognitif. Penelitian ini menggunakan pendekatan kualitatif dengan tipe penelitian etnografi. Metode penelitian yang digunakan adalah observasi partisipasi, wawancara mendalam dan studi dokumentasi. Hasil penelitian mengungkapkan pola pikir masyarakat Jorong Rumah Panjang penganut ajaran islam yang melaksanakan manjapuik limau tidak begitu saja muncul, pemahaman itu muncul berdasarkan pengalaman atau bukti yang telah terjadi. Masyarakat Jorong Rumah Panjang yang melaksanakan manjapuik limau disebabkan berberapa alasan yaitu pengetahuan masyarakat tentang manjapuik limau dan keyakinan terhadap kesaktian roh nenek moyang.
\end{abstract}

Kata kunci: Manjapuik Limau, Upacara Perkawinan, Sistem Pengetahuan

Abstract

This article aims to explain the knowledge of people of Jorong Rumah Panjang in manjapuik limau before the wedding ceremony and describe the beliefs of the people of Jorong Rumah Panjang adherents of Islam against the ancestors' spiritual powers. This research was analyzed by the theory of Ethnoscience developed by James P. Spradley. Ethnoscience emphasizes that the data presented is cognitive data. This research used a qualitative approach with ethnographic research type. The research methods which were used are participant observation, in-depth interview and documentation study. The results of the research reveal the mindset of Jorong Rumah Panjang's people adherents of Islam who implement manjapuik limau were not just appearing, the understanding was based on experience or evidence that has occurred. The people of Jorong Rumah Panjang implement manjapuik limau due to several reasons namely the people's knowledge about manjapuik limau and belief in the ancestors' spiritual power.

Keywords: Manjapuik Limau, Marriage Ceremony, System Knowledge

\section{Received: October 15, $2019 \quad$ Revised: November 5, $2019 \quad$ Published: November 6, 2019}




\section{Pendahuluan}

Manjapuik limau merupakan salah satu bagian penting dalam tradisi perkawinan di Jorong Rumah Panjang Nagari Selayo Tanang Bukit Sileh. Tradisi ini dilakukan sekurang-kurangnya 7 (tujuh) hari sebelum dilaksanakannya perkawinan. Setelah ditetapkannya tanggal perkawinan maka calon pengantin bersama Induak Limau akan pergi ke tampek atau kuburan nenek moyang yang dikeramatkan dengan membawa limau gadang (jeruk besar) satu buah, limau kapeh (jeruk kapas) satu buah, limau puruik (jeruk purut) satu buah, ureh $^{1}$, kumayan (kemenyan), dan aia (air). Induak limau adalah orang yang mengerti tentang bagaimana manjapuik limau.

Setelah sampai di tampek, limau yang sudah disiapkan di masukan ke dalam wadah berisi air, lalu membakar kumayan pada sabuik karambia ${ }^{2}$ yang sudah dibakar. Limau yang sudah dimasukan ke dalam wadah yang berisi air beserta ureh tadi diasapkan di atas kumayan. Selanjutnya air yang berisi limau diberikan kepada calon pengantin untuk diusapkan ke mukanya sembari meminta restu agar perkawinan yang akan dilaksanakan nantinya akan baik-baik saja. Limau dan ureh tadi akan dibawa pulang kembali ke rumah keluarga yang anaknya akan menikah lalu disimpan ${ }^{3}$.

Keluarga yang ada di Jorong Rumah Panjang Nagari Selayo Tanang Bukit Sileh mempunyai tampek atau kuburan nenek moyang yang dikeramatkan berdasarkan clan. Di nagari Selayo Tanang Bukit Sileh terdapat bebarapa clan yang menempati wilayah tersebut yaitu melayu tinggi, melayu tangah, melayu nan ampek, chaniago, chaniago sipanjang, tanjuang dan bendang. Tampek yang berlokasi di Jorong Rumah Panjang tidak ada. Nagari Selayo Tanang Bukit Sileh hanya ada 1 (satu) tampek yang dimiliki oleh suku melayu tinggi dan tampek tersebut berada di Jorong Lakuek. Sedangkan tampek yang dimiliki oleh clan lain berada di luar nagari Selayo Tanang Bukit Sileh.

Seperti mayarakat Minangkabau lainnya, di Jorong Rumah Panjang kelompok kekerabatan terkecil adalah samande (se-ibu) yaitu mereka yang lahir dari ibu yang sama dengan pimpinan saudara laik-laki yang biasa disebut mamak. Selanjutnya gabungan dari samande disebut jurai, kemudian gabungan dari jurai disebut saparuik yang biasa dihitung sampai lima keturunan yang dipimpin oleh tungganai. Suku terdiri dari beberapa paruik, suku merupakan unit utama dari struktur sosial Minangkabau, dan seseorang tidak dapat dipandang sebagai orang Minangkabau kalau tidak memiliki suku. Suku ini kemudian akan membentuk Nagari, syarat untuk berdirinya Nagari yaitu terdiri dari empat suku. ${ }^{4}$

Selain pergi ke tampek, juga diharuskan kepada pasangan yang akan menikah untuk manjapuik limau ke kuburan ${ }^{5}$ orang tua apabila sudah meninggal dengan tujuan meminta restu untuk melaksanakan pernikahan. Setelah tradisi itu dilaksanakan maka calon pengantin dilarang untuk keluar dari kawasan rumah, hal itu dilakukan karena masyarakat di Jorong Rumah Panjang percaya bahwa akan terjadi hal buruk yang akan menimpa calon pengantin jika melanggar ${ }^{6}$.

Masyarakat Jorong Rumah Panjang Nagari Selayo Tanang Bukit Sileh melaksanakan aktivitas Manjapuik limau karena meyakini kekuatan roh nenek moyang mereka yang semasa hidupnya memiliki kesaktian. Masyarakat meyakini bahwa akan ada hukuman bagi calon pengantin yang tidak melaksanakan manjapuik limau. Masyarakat Jorong Rumah Panjang Nagari Selayo Tanang percaya jika tradisi tersebut tidak dilaksanakan, maka roh nenek moyang mereka akan marah dan mendatangkan bahaya kepada calon pengantin karena tidak meminta restu kepada mereka sebelum perkawinan. Bahaya yang dimaksud misalkan saja datangnya penyakit

${ }^{1}$ Ureh adalah sejenis tumbuhan yang sering digunakan sebagai obat

${ }^{2}$ Sabuik Karambia adalah batok kelapa yang biasa digunakan masyarakat minangkabau untuk mempermudah menghidupkan api.

${ }^{3}$ Rofatma (51 Tahun.) Sebagai warga. Wawancara pada tanggal 16 Februari 2017.

${ }^{4}$ Mochtar Naim. 1984. Merantau Pola Migrasi Suku Minangkabau. Yogyakarta: UGM Press. Hal: 19

${ }^{5}$ Kuburan biasanya juga merupakan suatu tempat keramat yang dipakai sebagai tempat upacara keagamaan.Hal ini dapat dimengerti karena kuburan dibayangkan sebagai tempat orang paling mudah berhubungan dengan ruhruh nenek moyang yang meninggal (Koentjaraningrat.1972. Beberapa Pokok Antropologi Sosial. Jakarta: Dian Rakyat. Hal: 245)

${ }^{6}$ Marnizar (48 Tahun). Sebagai warga. Wawancara tanggal 15 Februari 2017

Culture \& Society: Journal of Anthropological Research Vol. 1, No. 2, Th. 2019 
kepada laki-laki, perempuan atau anak dari pasangan yang sudah melangsungkan perkawinan tetapi tidak melakukan manjapuik limau.

Hal itu diperkuat dengan adanya adanya peristiwa yang diyakini oleh masyarakat sebagai hukuman kepada keluarga yang tidak melaksanakan manjapuik limau, Anak dari keluarga tersebut terserang penyakit aneh yang bagi masyarakat adalah hukuman dari roh nenek moyang mereka karena tidak meminta izin terlebih dahulu dengan mengikuti tradisi yang sudah mendarah daging. Peristiwa ini terjadi pada tahun 2012, yang terjadi kepada anak laki-laki yang sekarang berumur kurang lebih 5 tahun. Anak tersebut hanya terbaring di tempat tidur.

Mayoritas masyarakat Jorong Rumah Panjang Nagari Selayo Tanang adalah penganut agama Islam. Islam mengajarkan untuk mempercayai segala sesuatu yang ada di Qur'an maupun Hadist. Ajaran Islam mengungkapkan apabila seseorang manusia bertawakkal kepada selain Allah dalam perkara yang tidak bisa melakukannya selain Allah, seperti tawakkal kepada orang yang sudah meninggal dunia dan orang-orang yang ghaib serta seumpama mereka dalam menolak bahaya, mendapatkan manfaat dan rizqi, berarti dia telah menyekutukan Allah dengan syirik besar. $^{7}$

Manjapuik limau menjadi sesuatu keharusan bagi seseorang yang akan melaksanakan perkawinan. Suatu hal yang tidak baik apabila tidak melaksanakan. Adanya konsekuensi atau hukuman apabila tidak melaksanakan manjapuik limau membuat masyarakat di Jorong Rumah Panjang tetap melaksanakan manjapuik limau. Adanya peristiwa yang benar-benar terjad kepada masyarakat yang tidak melaksankan manjapuik limau sebelum upacara pernikahan menjadikan suatu pelajaran tersendiri bagi masyarakat. Jika dikaitkan dengan sistem kepercayaan masyarakat Nagari Selayo Tanang yang menganut agama Islam, tentu keadaan seperti ini kian menarik untuk dikaji, karena seharusnya seseorang yang beragama Islam tidak melakukan hal-hal yang tidak diperbolehkan.

Kajian mengenai manjapuik limau sebelum upacara perkawinan belum ada. Namun ada beberapa studi relevan yang terkait dengan kajian ini yaitu (1) Ritual Sale dalam Upacara Perkawinan Orang Rimbo di Pemenang Kabupaten Merangin, Jambi oleh nani widiasti ${ }^{8}$ dan (2) Tradisi Syukuran Muyang Tampek Baringin pada Masyarakat Batu Gadang Kecamatan Lubuk Kilangan Kota Padang oleh Mira Eka Sari ${ }^{9}$.

Berdasarkan masalah yang telah peneliti jabarkan di atas maka yang menjadi pertanyaan penelitian yaitu (1) Bagaimana pengetahuan masyarakat Jorong Rumah Panjang Nagari Selayo Tanang Bukit Sikeh tentang manjapuik limau? (2) Mengapa masyarakat Jorong Rumah Panjang Nagari Selayo Tanang Bukit Sileh penganut ajaran Islam yang meyakini kesaktian roh nenek moyang dalam Manjapuik Limau? Berdasarkan masalah yang telah peneliti jabarkan di atas maka tujuan yang hendak dicapai dalam penelitian ini yaitu: (1) untuk mendeskripsikan pengetahuan masyarakat Jorong Rumah Panjang Nagari Selayo Tanang Bukit Sileh tentang menjapuik limau (2) untuk menjelaskan perilaku masyarakat Jorong Rumah Panjang Nagari Selayo Tanang Bukit Sileh penganut ajaran Islam yang meyakini kesaktian roh nenek moyang dalam Manjapuik Limau.

Penelitian ini dianalisis dengan teori etnosains oleh James P Spradley, Ethnoscience adalah "system of knowledge and cognittion typical of given culture" bukannya metode penelitian. ${ }^{1011}$ Penekanannya di sini adalah pada sistem pengetahuan masyarakat, yang merupakan pengetahuan yang khas dari suatu masyarakat, dan berbeda dengan sistem pengetahuan masyarakat lain. Mengingat pengetahuan ini sangat luas lingkupnya, bisa menyangkut berbagai macam hal, maka

\footnotetext{
${ }^{7}$ Khairul Hadi. 2013. Makna Syirik dalam al-Qur'an (Kajian Tafsir Tematik dan Kaitannya dengan Fenomena Kehidupan Seakarang). Skripsi. UIN Sultan Syarif Kasim: Hal: 3

${ }^{8}$ Nani Widiasti. Ritual Sale dalam Upacara Perkawinan Orang Rimbo di Pemenang kabupaten Merangin, Jambi. Skripsi. UNP. 2008.

${ }^{9}$ Mira Eka Sari. Tradisi Syukuran Muyang Tampek Baringin pada Masyarakat Batu Gadang Kecamatan Lubuk kilangan Kota Padang.Skripsi. Pendidikan Sosiologi-Antropologi. UNP. 2006

${ }^{10}$ Heddy Shri Ahimsa-Putra. 1985. Jurnal antropologi ethnosains dan etnometodologi sebuah perbandingan. Yogyakarta: UGM..

${ }^{11}$ Lihat Achmad Fedyani Saifuddin. 2006. Antropologi Kontemporer: Suatu Pengantar Kritis Mengenai

Paradigma. Jakarta: Kencana
}

Culture \& Society: Journal of Anthropological Research Vol. 1, No. 2, Th. 2019 
dalam penelitiannya seorang ahli antropologi biasanya tidak akan menggali semua isi pengetahuan yang ada, melainkan hanya pengetahuan tentang hal-ahal tertentu saja dalam kehidupan atau dunia mereka yang dia minati. ${ }^{12}$

Etnosain menekankan bahwa data yang disodorkan adalah data kognitif (mental codes). Orang antropologi kognitif ini berasumsi bahwa setiap masyarakat mempunyai sistem yang unik dalam mempersiapkan dan mengorganisasikan fenomena material, seperti benda-benda, kejadian, perilaku, dan emosi. ${ }^{13}$ Etnosains mendeskripsikan makna-makna yang hidup dalam masyarakat atau dasar makna yang diberikan oleh orang-orang yang diteliti. Menurut Malinowski "to grasp the native's point of view, his relation to life, to realize his vision of his world" menemukan makna dari suatu kebudayaan melalui klasifikasi lokal yang dibuat masyarakat dari suatu kebudayaan. Kebudayaan sebagai pengetahuan dan manusia sebagai makhluk sosial, dipakai untuk memahami dan menginterpretasikan lingkungan dan pengalaman, tidak lain karena semua itu akan mempengaruhi kelakuannya. ${ }^{14}$

\section{Metode Penelitian}

Penelitian ini dilakukan di Jorong Rumah Panjang, Nagari Selayo Tanang Bukik Sileh, Kecamatan Lembang Jaya, Kabupaten Solok. Penelitian ini dilakukan pada bulan November 2017 sampai Januari 2018. Dilihat dari pendekatannya penelitian ini merujuk pada pendekatan kualitatif. Penelitian kualitatif bermaksud untuk menghasilkan data deskriptif berupa kata-kata tertulis atau lisan dari orang-orang, dan perilaku yang dapat diamati. ${ }^{15}$ Dilihat dari segi tipenya, penelitian ini termasuk penelitian etnografi. Informan penelitian dipilih secara sengaja (purposive sampling), berjumlah 24 orang.

Data dikumpulkan dengan cara observasi partisipasi, observasi adalah metode atau caracara menganalisis dan mengadakan catatan secara sistematis mengenai tingkah laku dengan melihat atau mengamati individu atau kelompok secara langsung. ${ }^{16}$ Wawancara yang digunakan adalah wawancara mendalam (in-depth interview), wawancara adalah bentuk komunikasi antara dua orang, melibatkan seseorang yang ingin memperoleh informasi dari seseorang lainnya dengan mengajukan pertanyaan - pertanyaan, berdasarkan tujuan tertentu, ${ }^{17}$ dan teknik pengumpulan data yang terakhir adalah studi dokumen, Studi dokumentasi dilakukan untuk memperkuat data yang telah didapatkan dari observasi dan wawancara atau sebagai sumber baru yang mendukung dan berhubungan dengan permasalahan yang diteliti. Agar data yang diperoleh lebih bisa dipercaya (absah), maka dalam penelitian ini dilakukan triangulasi khususnya triangulasi sumber. Data dianalisis dengan mengacu pada model teknik etnografi oleh James Spradley yaitu metode Development Research Sequence atau Alur Penelitian Maju Bertahap.

\section{Hasil dan Pembahasan}

\section{Manjapuik Limau Bagi Masyarakat Jorong Rumah Panjang Nagari Selayo Tanang Bukit Sileh}

\section{Proses Dalam Manjapuik Limau}

Pengetahuan masyarakat Jorong Rumah Panjang dalam Manjapuik limau sebelum upacara perkawinan dapat dilihat dari perilaku masyarkat dalam proses pelaksanaan manjapuik limau. Adapun beberapa proses dalam manjapuik limau adalah sebagai berikut:

\footnotetext{
12 ibid

${ }^{13}$ Spradley. 1997. Metode Etnografi. Yogyakarta: Pt Tiara Wacana. Hal: xx (Kata pengantar dari Dr. Amri Marzali).

${ }^{14}$ Hari Purwanto. 2005. Kebudayaan dan Lingkungan Dalam Perspektif Antropologi. Yogyakarta:Pustaka Pelajar Offset: Hal: 37.

${ }^{15}$ Lexy J. Moleong. 2000. Metodologi Penelitian Kualitatif. Bandung: Remaja Rosdakrya. Hal: 3

${ }^{16}$ Basrowi dan Suwandi. Memahami Penelitian Kualitatif. 2008. Jakarta: Rineka Cipt. Hal: 93-94

${ }^{17}$ Deddy Mulyana. 2010. Metodologi Penelitian Kualitatif. Bandung: PT. Remaja Rosdakarya. Hal: 180
}

Culture \& Society: Journal of Anthropological Research Vol. 1, No. 2, Th. 2019 


\section{a. Manjapuik Induak Limau}

Induak limau adalah orang yang di tuakan dari keluarga yang akan melaksanakan perkawinan, misalnya Ibu dari orang tua mempelai (Amak) atau kakak dari Ibu (Uwo). Biasanya induak limau ini adalah orang yang mengerti tentang proses dalam manjapuik limau. Jauh-jauh hari keluarga harus memberitahu induak limau kapan akan melaksankan manjapuik limau, lalu setelah hari ditentukan keluarga harus mencari separangkat limau lalu memberikan kepada induak limau. Saat hari pelaksanaan manjapuik limau keluarga akan menjeput induak limau dan mengajak untuk ke tampek.

\section{b. Membersihkan Tampek}

Setelah sampai di tampek calon pengantin bersama induak limau harus membersihkan tampek terlebih dahulu. Hal tersebut dilakukan sebagai penghormatan kepada roh nenek moyang yang berada di tampek. Tampek itu diibaratkan rumah oleh masyarakat Jorong Rumah Panjang. Maka salah satu keharusan bagi calon pengantin yang akan melaksanakan manjapuik limau membersihkan tampek, karena masyarakat percaya apabila calon pengantin dan induak limau datang dengan niat dan sikap yang baik roh nenek moyang juga akan merasa lebih senang.

\section{c. Membakar Kemenyan}

Setelah tampek tadi dibersihkan maka langkah selanjutnya adalah membakar kemenyan. Sabuik karambia yang sudah di beri minyak tanah sestelah sampai di tampek dibakar dan tunggu sampai api padam atau bisa dipadamkan sendiri setelah itu kemenyan tadi di letakkan di atas bara api sabuik karambia tersebut. Kemenyan di anggap memiliki mistis yang sangat erat kaitan nya dengan hal ghaib, masyarakat percaya bahwa dengan membakar kemenyan akan lebih memudahkan roh nenek moyang mendengar permintaan mereka saat melaksanakan manjapuik limau.

\section{d. Maasok Limau}

Sabuik karambia yang sudah dibakar dan di berikan kemenyan di atasnya akan menghasilkan aroma kemenyan yang sangat pekat. Setelah itu maka induak limau akan Maasok limau yang sudah di siapkan tadi dengan asap yang dihasilkan dari sabuik karambia beserta kemenyan yang sudah dibakar. Maasok limau itu limau yang sudah disiapkan tadi di pegang sambil di letakkan di atas sabuik karambia yang sudah dibakar dan diberi kemenyan. Hal itu bertujuan agar asap kemenyan tadi meresap ke dalam limau yang nantinya akan di basuhkan oleh kedua mempelai.

\section{f. Mangarek limau dan mencuci muka oleh kedua mempelai}

Setelah maasok limau langkah selanjutnya adalah mangarek limau tersebut dan memasukkan ke dalam wadah yang sudah berisi air. Kedua mempelai akan membacakan do'a dan harapan mereka di dalam hati. Setelah itu limau yang sudah dimasukkan ke dalam wadah berisi air di basuhkan ke muka kedua mempelai yang di bantu oleh induak limau.

\section{Pengetahuan Masyarakat Tentang Manjapuik Limau}

Masyarakat Jorong Rumah Panjang memiliki suatu pengetahuan yang khas dalam manjapuik limau. Pengetahuan masyarakat tentang manjapuik limau adalah sebagai berikut:

\section{a. Istilah Manjapuik Limau}

Manjapuik limau merupakan bagian penting yang harus diperhatikan oleh masyarakat di Jorong Rumah Panjang Nagari Selayo Tanang Bukit Sileh apalagi bagi keluarga yang anaknya akan melangsungkan perkawinan. Tradisi ini secara turun-temurun dilaksanakan oleh masyarakat Nagari Selayo Tanang Bukit Sileh karena dianggap dapat mengakibatkan terjadinya hal buruk pada keluarga pengantin nantinya. Adanya konsekuensi tersebut menjadikan alasan masyarakat untuk tetap mempertahakan serta melaksanakan tradisi tersebut sampai sekarang.

Istilah manjapuik limau memang sangat beragam, dari hasil temuan dalam wawancara bersama masyarakat di Jorong Rumah Panjang Nagari Selayo Tanang Bukit Sileh ada tiga 
penamaan masyarakat, yaitu: (1) Mantauwauan Limau ka Tampek (2) Baurek Kayu dan (3) Bainduak Limau. Namun pada artian, maksud dan tujuan dari ketiga istilah di atas tetap sama saja.

Pada masa sekarang masyarakat lebih menyebutkan dengan istilah manjapuik limau. Manjapuik limau itu adalah mengantarkan limau oleh calon pengantin bersama induak limau ke tampek atau kuburan nenek moyang yang dikeramatkan. Limau yang dimaksud itu adalah yang terdiri dari limau gadang, limau kapeh, limau lunggo, limau puruik, ureh, kumayan, air, sabuik karambia, rokok 1 batang, uang seikhlasnya dan api-api.

Dari hal tersebut memang pada realitanya bukan limau itu yang dijapuik karena limau sudah di bawa dari rumah namun dapat disimpulkan bahwa pengetahuan masyarakat Jorong Rumah Panjang tentang artian manjapuik limau adalah doa-doa dan harapan yang disampaikan pada saat manjapuik limau di tampek tadi yang dijapuik sehingga bisa dibawah pulang atau bisa terkabulkan dan diharapkan kepada calon pengantin telah melaksanakan manjpauik limau tadi akan terlindungi dari hal-hal buruk. .

\section{b. Waktu Manjapuik Limau}

Manjapuik limau sebagai salah satu tradisi yang ada di Jorong Rumah Panjang Nagari Selayo Tanang Bukit Sileh, tentunya memiliki hari baik dan hari tidak baik untuk melaksanakan manjapuik limau berdasarkan pengetahuan masyarakat. pengetahuan itu telah di miliki sejak dulu dan diteruskan secara turun-temurun. Baik atau buruknya hari untuk menjapuik limau sudah di percayai oleh masyarakat dari dulu, bahkan bukan hanya saat manjapuik limau saja tetapi dalam menentukan hari untuk melaksanakan perkawinanpun harus disesuaikan dengan hari baik. Waktu yag paling baik manjapuik limau adalah pada pagi hari sekitar pukul $07.00-09.00$ WIB antara senin dan kamis.

Pengetahuan masyarakat terhadap hari baik dan hari buruk dalam manjapuik limau sudah diturunkan dari dulu. Masyarakat menganggap bahwa hari baik itu harus disegerakan dan hari buruk jangan dikerjakan. Seperti hari baik pada hari senin dan kamis karena masyarakat percaya bahwa hari senin dan kamis adalah hari baik yang di sunahkan oleh Nabi Muhammad SAW sesuai dengan ajaran Islam tentunya. Sedangkan hari buruk yaitu pada selasa dan sabtu masyarakat juga mendapatkan pengetahuan dari nenek moyang mereka sehingga mereka kurang memahami mangapa hari selasa dan sabtu dikatakan sebagai hari buruk atau tidak baik untuk melaksanakan manjapuik limau atau melangsungkan perkawinan.

\section{c. Tempat Manjapuik Limau}

Manjapuik limau sebagai tradisi yang sudah turun-temurun dilaksanakan oleh masyarakat Jorong Rumah Panjang Nagari Selayo Tanang Bukit Sileh tentunya memiliki tempat untuk melaksanakan tradisi tersebut. Tempat melaksanakan manjapuik limau di namakan oleh masyarakat yaitu tampek. Tampek adalah kuburan yang dikeramatkan oleh masyarakat di Nagari Selayo Tanang Bukit Sileh. Masyarakat menganggap bahwa orang yang di kuburkan di tampek itu memiliki kekuatan yang sakti semasa hidupnya. Masyarakat percaya apa yang diinginkan saat mengunjungi tampek untuk melaksanakan manjapuik limau akan terkabul asalkan dengan niat yang baik dan persayaratan yang cukup serta malaksanakannya dihari yang tepat yaitu hari baik bagi masyarakat.

Masyarakat mempercayai bahwa tampek itu sakti. Keluarga yang ada di Nagari Selayo Tanang Bukit Sileh mempunyai tampek atau kuburan nenek moyang yang dikeramatkan berdasarkan clan. Jorong Rumah Panjang Nagari Selayo Tanang Bukit Sileh terdapat bebarapa suku yang menempati wilayah tersebut yaitu melayu tinggi, melayu tangah, melayu nan ampek, chaniago, chaniago sipanjang, tanjuang dan bendang.

Keluarga yang ada di Jorong Rumah Panjang Nagari Selayo Tanang Bukit Sileh mempunyai tampek atau kuburan nenek moyang yang dikeramatkan berdasarkan clan. Di nagari Selayo Tanang Bukit Sileh terdapat bebarapa clan yang menempati wilayah tersebut yaitu melayu tinggi, melayu tangah, melayu nan ampek, chaniago, chaniago sipanjang, tanjuang dan bendang. Tampek yang berlokasi di Jorong Rumah Panjang tidak ada. Nagari Selayo Tanang Bukit Sileh hanya ada 1 (satu) tampek yang dimiliki oleh suku melayu tinggi dan tampek tersebut berada di 
Jorong Lakuek. Sedangkan tampek yang dimiliki oleh clan lain berada di luar nagari Selayo Tanang Bukit Sileh.

\section{Keyakinan Masyarakat Terhadap Kesaktian Roh Nenek Moyang}

Masyarakat Jorong Rumah Panjang meyakini kekuatan sakti yang dimiliki oleh roh nenek moyang merupakan hasil dari proses belajar. Proses belajar yang dimaksud adalah hasil pengetahuan masyarakat merupakan cerita turun-temurun oleh nenek moyang mereka. Cerita atau pengalamanan tersebut akan terus berlanjut dan berulang. Adapun beberapa keyakinan masyarakat terhadap kesaktian roh nenek moyang adalah sebagai berikut:

\section{a. Roh Nenek Moyang Itu Sakti}

Masyarakat di Jorong Rumah Panjang Nagari Selayo Tanang Bukit Sileh bukan tanpa sebab masih mempertahankan dan melaksanakan manjapuik limau sebelum upacara perkawinan. Namun hal itu dikarenkan masyarakat percaya bahwa roh nenek moyang masih berada disekitar mereka, sehingga setiap kegiatan ataupun upacara yang dilaksanakan haruslah meminta izin dan memberitahukan kepada roh nenek moyang mereka. Seperti halnya manjapuik limau ini selain meminta doa-doa agar keluarga yang dibina oleh pengantin nantinya baik-baik saja, hal itu juga bertujuan untuk meminta izin dan memberitahukan kepada leluhur mereka bahwa anaknya akan melasanakan perkawinan.

Masyarakat yang melaksankan manjapuik limau bukan hanya untuk meminta doa tetapi hal itu juga dilakukan untuk meminta izin kepada leluhur mereka agar leluhur mereka tahu bahwa ada anak dari keluarganya akan melaksanakan perkawinan.

Selain itu manjapuik limau masih menjadi bagian penting dalam rangkaian upacara perkawinan di Jorong Rumah Panjang Nagari Selayo Tanang Bukit Sileh dikarenkan masyarakat mempercayaai bahwa nenek moyang di tampek itu sakti. Kepercayaan itu didapatkan dari cerita turun-temurun yang mengatakan bahwa nenek moyang itu semasa hidupnya memiliki kekuatan sakti seperti bisa menyembuhkan berbagai macam penyakit.

Masyarakat Jorong Rumah Panjang Nagari Selayo Tanang Bukit Sileh percaya bahwa roh nenek moyang yang berada di tampek memiliki kekuatan sakti. Masyarakat percaya bahwa kesaktian nenk moyang itu sudah ada dari dulu semasa dia hidup. mampu menyembuhkn berbagai macam penyakit dan mengabulkan permintaan membuat salah satu alasan masyarakat msih meyakini roh nenek moyang dengan melaksankan manjapuik limau sebelum upcara perkawinan. Dengan melaksanakan manjapuik limau masyarakat berharap aka nada perlindungan dari leluhurnya.

Masyarakat di Jorong Rumah Panjang Nagari Selayo Tanang Bukit Sileh merupakan masyarakat yang mayoritas beragama Islam. Tetapi kebanyakan masyarakat masih melaksanakan manjapuik limau padahal dalam Qur'an sebagai pedoman hidup umat Islam aktivitas manjapuik limau itu tidaklah diperbolehkan. Masyarakat di Jorong Rumah Panjang Nagari Selayo Tanang Bukit Sileh masih melaksanakan manjapuik limau yang sudah dilaksanakan oleh nenek moyang mereka jauh sebelum masuknya ajaran Islam. Pengaruh anisme, dinamisme, dan juga ajaran Hindu-Budha yang lebih dulu masuk sebelum Islam mengakibatkan terjadinya sinkretisme ${ }^{18}$. Artinya kepercayaan yang telah dianut oleh nenek moyangnya mempengaruhi sistem pengetahuan masyarakat Islam setempat dalam memaknai manjapuik limau.

\section{b. Tampek Sebagai Perantara Doa}

Pada masyarakat di Nagari Selayo Tanang Bukit Sileh tampek dipercaya sebagai perantara doa. Mereka beranggapan bahwa roh nenek moyang berada lebih dekat dengan Tuhan sehingga setiap doa dan harapan akan lebih cepat tersampaikan. Kepercayaan itu lebih lanjut diteruskan masyarakat dengan melaksanakan manjapuik limau sebelum upacara perkawinan. Manjapauik

\footnotetext{
${ }^{18}$ Oleh Haviland, sinkretisme itu terjadi dalam proses akulturasi antara satu budaya kepada budaya yang lain. Lebih tepatnya dikatakan sebagai percampuran unsur-unsur lama untuk membentuk sistem yang baru. William A. Havilland, 1988, Antropologi Edisi Keempat Jilid 2. Jakarta: Erlangga. Hal. 263
} 
limau dilakukan di tampek atau kuburan nenek moyang yang dikeramatkan bertujuan agar doa dan harapan pengantin bisa lebih cepat tersampaikan.

Warga Jorong Rumah Panjang Nagari Selayo Tanang Bukit Sileh memiliki pengetahuan bahwa roh nenek moyang lebih dekat kepada Tuhan jadi setiap permintaan yang diminta akan lebih cepat tersampaikan. Hal inilah yang membuat masyarakat Nagari Selayo Tanang Bukit Sileh masih mempercayai roh nenek moyang dalam aktivitas manjapuik limau tersebut.

\section{c. Konsekuensi dan Bukti}

Kepercayaan masyarakat terhadap manjapuik limau lahir dikarenakan adanya suatu pola pikir masyarakat yang menganggap bahwa jika tidak melaksanakan manjapuik limau sebelum upacara perkawinan maka akan terjadi sesuatu hal buruk atau yang dinamakan masyarakat dengan katinggalan limau. Hal buruk yang dimaksud bisa berupa datangnya penyakit kepada calon pengantin maupun anak dari pernikahan mereka nantinya.

Masyarakat meyakini akan terjadi sesuatu hal buruk apabila tidak membawa anak yang akan melaksanakan perkawinan ke tampek untuk manjapuik limau. Setiap keluarga tentunya tidak ingin melihat perkawinan anaknya nanti akan mendapatkan musibah, hal tersebut mendorong masyarakat untuk tetap malaksankan manjapuik limau agar hal buruk yang dikhawatirkan tidak terjadi.

Dari wawanacara yang dilakukan oleh peneliti menghasilkan beberapa konsekuensi yang terjadi apabila tidak melaksanakan manjapuik limau yang telah disebutkan oleh masyarakat, yaitu sebagi berikut:

Tuli

Tuli merupakan keadaan dimana tidak berfungsinya telinga sebagai indra pendengaran. Setiap orang yang menderita ketulia atau tuli akan sulit mendengar bahkan tidak bisa mendengarkan suara apapun. Salah satu konsekuensi yang terjadi apabila tidak melaksankan menjapuik limau adalah anak dari perkawinan tersebut akan menderita penyakit tuli. Hal itu di buktikan dengan kasus yang terjadi pada kedua anak laki-laki Ibu Ulfayenti yang beranam Kris (5 Tahun) dan Marvel (10 Tahun) tidak dapat mendengar atau tuli.

Masyarakat percaya dengan konsekuensi yang terjadi karena adanya kebenaran atas pengetahuan masyarakat tentang hal buruk yang terjadi apabila tidak melaksanakan manjapuik limau sehingga masyarakat takut hal itu terjadi kepada keluarganya tetap melaksankan manjapuik limau. Ibu Ulfayenti menikah pada tahun 2000 dan dikarunia 2 orang anak yang beranama: Kris (5 Tahun), dan Marvel (10 Tahun). Kedu anak Ibuk Ulfayenti mengalami penyakit tuli yang bagi Ibu Ulfayenti sendiri disebabkan karena tidak manjapuik limau sebelum menikah.

\section{Sawan atau sakit ayan}

Sawan atau sakit ayan juga bisa dikenal dengan penyakit epilepsi. Masyarakat di Nagari Selayo Tanang menggap bahwa penyakit sawan atau ayan merupakan salah satu konsekuensi yang terjadi apabila tidak melaksankan manjapuik limau. Penyakit ini ditandai dengan kejangkejang dan mengeluarkan buih dari mulut pada penderita.

Biasanya penderita yang mengalami penyakit ini harus dijauhkan dari api dan air, karena jika penderita sawan atau sakit ayan kumat maka akan sangat berbahaya.

Masyarakat menjalankan apa yang sudah ada seperti manjapuik limau dikarenakan kepercayaan mereka akan hal buruk yang terjadi apabila bila tidak dilaksanakan. Sebagai makhluk sosial tentunya masyarakat saling mengingatkan kepada sesame anggota masyarakatnya. Tetapi ketika ada masyarakat yang percaya dan ada yang tidak percaya maka itu adalah pilihan mereka

\section{Bodoh pada anak atau penyakit aneh}

Kebodohan pada anak merupakan hal yang sangat ditakutkan oleh setiap keluarga. Namun kebodohan yang dimaksud bukanlah bodoh karena tidak mau belajar, tetapi bodoh yang dimaksud adalah seorang anak yang tidak bisa melakukan apapun padahal seusianya sudah sangat aktif. Hal itu terjadi pada anak laki-laki dari Nilawati yang sudah berumur 5 tahun tetapi anaknya tidak bisa beraktifitas layaknya anak semuran dia. Dari hasil observasi peneliti pada tanggal 26 November 
2017, peneliti melihat anak laki-laki Ibu Nilawati tetapi Ibuk Nilawati menolak untuk peneliti mengambil gambar anaknya. Maka dari itu peneliti tidak memiliki dokumentasi mengenai ini. Anak laki-laki yang sudah berumur 5 tahun tersebut diletakkan diatas kasur di dalam ruang tamu, anak tersebut hanya bisa mengerakkan tangannya sedikit dan menangis. Masyarakat percaya bahwa penyakit itu disebabkan karena Ibu Nilawati sebelum menikah tidak melaksanakan manjapuik limau.

Pola pikir masyarakat yang beranggap bahwa akan terjadi hal buruk kepada calon pengantin yang tidak melaksanakan manjapuik limau terlebih dahulu sebelum upacara perkawinan menjadikan momok kepada masyarakat sehingga tetap mempertahankan dan melaksanakan sampai sekarang.

Perilaku masyarakat Nagari Selayo Tanang Bukit Sileh yang melaksanakan manjapuik limau dianalisis dengan teori etnosain oleh James P Spradley. Beliau mengatakan Ethnoscience adalah system of knowledge and cognition typical of given culture..$^{19}$ Perilaku masyarakat Nagari Selayo Tanang Bukit Sileh yang melaksanakan manjapuik limau dilatarbelakangi oleh pola pikir atau sistem pengetahuan dari masyarakat tersebut. Kebiasaan yang sudah dilakukan secara terus menerus ini telah terkonstruksi di dalam pola pikir masyarakat Nagari Selayo Tanang Bukit Sileh, hal ini bisa dilihat dari perilaku masyarakat Nagari Selayo Tanang Bukit Sileh yang masih melaksanakan manjapuik limau dan percaya akan konsekuensi apabila tidak melaksankannya.

Menurut Spradley, budaya sebagai sistem pengetahuan diperoleh manusia proses belajar, yang mereka gunakan untuk menginterpretasikan dunia sekeliling mereka, dan sekaligus menyusun strategi perilaku dalam menghadapi dunia sekeliling mereka ${ }^{20}$. Lebih lanjut ditekankan budaya ditafsirkan sebagai model-model untuk mengklasifikasikan lingkungan atau situasi sosial yang dihadapi. Pengkajian di sini bertujuan untuk mengetahui gejala-gejala materi mana yang dianggap penting oleh warga masyarakat dan bagaimana mereka mengorganisir berbagai gejala tersebut dalam sistem pengetahuan mereka.

\section{Kesimpulan}

Dari hasil penelitian wawancara, observasi, dan studi dokumentasi diperoleh bahwa masyarakat Jorong Rumah Panjang nagari Selayo Tanang Bukit Sileh meyakini kesaktian roh nenek moyang dalam manjapuik limau dilatarbelakangi oleh beberapa hal, yaitu: (1) masyarakat melaksanakan manjapuik limau di tampek karena roh nenek moyang di tampek adalah garis keturunan mereka. Setiap keluarga yang anaknya akan menikah, akan meminta induak limau untuk membawa anaknya untuk meminta izin serta memberi tahu kepada roh nenek moyang bahwa ada anak dari garis keturunan akan menikah. (2) masyarakat meyakini bahwa roh nenek moyang itu sakti. Kesaktian roh nenek moyang yang masyarakat yakini adalah dapat menyembuhkan penyakit dan mengabulkan permintaan. Pemahaman tersebut didapatkan dari pengalaman dan bukti-bukti yang telah diperoleh oleh masyarakat Jorong Rumah Panjang sehingga sebagai manusia biasa yang mempunyai sifat menghindari sebelum terjadi, membuat masyarakat tetap melaksanakan manjapuik limau sebelum perkawinan karena tidak ingin hal buruk menimpa keluarganya. (3) keyakinan masyarakat Jorong Rumah Panjang Nagari Selayo Tanang Bukit Sileh terhadap kekuatan roh nenek moyang dalam manjapuik limau diperoleh sebelum Islam masuk ke daerah ini. Kepercayaan animisme, dinamisme, dan Hindu-Budha yang lebih dulu masuk ke daerah ini masih melekat dan menyebabkan terjadinya sinkretisme.

\footnotetext{
${ }^{19}$ Heddy Shri Ahimsa-Putra. 1985. Jurnal antroologi. Ethnosains dan Etnometodologi Sebuah Perbandingan. Yogyakarta: UGM. Hal: 9

${ }^{20}$ James P Spradley. 1997. Metode Etnografi. Yogyakarta: PT Tiara Wacana Yogya. Hal xxi (Kata pengantar dari Dr. Amri Marzali).
}

Culture \& Society: Journal of Anthropological Research Vol. 1, No. 2, Th. 2019 


\section{Daftar Pustaka}

Ahimsa-Putra, Heddy Shri. (1985). Etnosains dan Etnometodologi: Sebuah Perbandingan Dalam masyarakat Indonesia. Majalah Ilmu-ilmu Sosial Indonesia. Jakarta: Lembaga Ilmu Pengetahuan Indonesia.

Basrowi dan Suwandi. (2008). Memahami Penelitian Kualitatif. Jakarta: Rineka Cipta.

Hadi, Khairul. (2013). Makna Syirik dalam al-Qur'an (Kajian Tafsir Tematik dan Kaitannya dengan Fenomena Kehidupan Seakarang). Skripsi. UIN Sultan Syarif Kasim.

Hari Purwanto. (2005). Kebudayaan dan Lingkungan Dalam Perspektif Antropologi.Yogyakarta: Alfabeta

Koentjaraningrat. (1972). Beberapa Pokok Antropologi Sosial. Jakarta: Dian Rakyat.

Moleong, Lexy J. (2000). Metodologi Penelitian Kualitatif. Bandung: Remaja Rosdakrya.

Mulyana, Deddy. (2010). Metodologi Penelitian Kualitatif. Bandung: PT. Remaja Rosdakarya.

Naim, Mochtar. (1984). Merantau Pola Migrasi Suku Minangkabau. Yogyakarta: UGM Press

Sari, Mira Eka. (2006). Tradisi Syukuran Muyang Tampek Baringin pada Masyarakat Batu Gadang Kecamatan Lubuk kilangan Kota Padang. Skripsi. Universitas Negeri Padang.

Saifuddin, Achmad Fedyani. (2006). Antropologi Kontemporer: Suatu Pengantar Kritis Mengenai Paradigma. Jakarta: Kencana

Spradley. 1997. Metode Etnografi. Yogyakarta: PT Tiara Wacana.

Widiasti, Nani. (2008). Ritual Sale dalam Upacara Perkawinan Orang Rimbo di Pemenang kabupaten Merangin, Jambi. Skripsi. Universitas Negeri Padang.

William A. Havilland. (1988). Antropologi Edisi Keempat Jilid 2. Jakarta: Erlangga. 